\title{
WTO, 20 Years in the Service of the World Economy
}

\section{Biljana Ciglovska}

Faculty of Economic Sciences, International University of Struga, Macedonia

\section{Florida Veljanoska}

Faculty of Economic Sciences, International University of Struga, Macedonia

Ilir Binaj

CPA, CGMA International Practice Partner at TPA Horwath Albania Adjuct Accounting professor at University of New York in Tirana

Doi:10.5901/ajis.2015.v4n2p527

\section{Abstract}

The year 2015 is not just a new number in the calendar; this year is very significant anniversary for existence and successfully functioning of the largest organization that has the largest responsibility for continuous world trade and keeping the stability of the world trading system. This year the World Trade Organization (WTO) celebrates 20 years of successfully regulating the world trade flows, 20 years of successfully adjustment and harmonization of economic and trade policies of the member countries and 20 years of adjustment and satisfying the interests of all countries in the world regardless their level of development, aiming to achieve the Millennium Goals. The set-outs of the institutionalization of the world trading system were not simple at all and they have started many years ago before the official establishment of the WTO. In those years also, the main goal was establishing a system that will put under control and regulate the international trade and the protection measures that were used in the same. The process of establishing the present system of rules, regulations, provisions and agreements for regulating the world trading system was getting across several stages, from which the last and actual now is still not finished. The ongoing Dora Round of negotiations hopefully will end this year with a successful decisions form which especially will benefit the Developing countries. In this respect, ministers from every WTO member finally took a major step in updating multilateral rules by unanimously agreeing to the so-called Bali Package. The 10 decisions which make up the package have economic significance by themselves, particularly for developing countries, but together they also opened a new chapter for multilateral trade negotiations.

Keywords: GATT, WTO, member countries, world trade system, harmonization, monitoring.

"We are living off the liberalization and reforms of the past. We need to update the rules and implement a new generation of trade reforms which would be so essential for development."

WTO Director-General Roberto Azevêdo

\section{Introduction}

Due to the difficulties in the International trade development in the post-war period, characterized with intensive protectionism and regionalism, there was a need for creating unified way for regulating the International trade. The process of institutionalization of the International economic relations began in 1944 in Breton Woods, when were established the International Monetary Fund (IMF) and the International Bank for Reconstruction and Development (IBRD). The aim was achieving institutional integrity in the three main directions: the international monetary flows, the international investments and the international trade.

\section{Institutionalization of the International Trading System}

\subsection{The General Agreement on Tariffs and Trade (GATT)}

The need for stabilization and recovery of the world economy from the Second World War consequences resulted with 
undertaking concrete measures by the great powers, especially the United States. Back in the early 40 's of the last century, the United States defend the idea for restoration of the world trade by free trade principles.

After establishing the IMF and the IBRD, the main aim was establishing a third institution which will be responsible for the trade issues within the international economic cooperation, with other words, this institution will be responsible for revival of the international trade and eliminating the detriments caused by the protectionist measures used during the war.

In the negotiations for creating the International Trade Organization (ITO), as a special UN`s agency were participating 50 countries and their aim was creation of the ITO on the UN Conference for trade and employment in Havana, Cuba in 1947 (See file at: http://www.wto.org/english/theWTO_e/whatis_e/tif_e/fact4_e.htm.) The intention was realizing the idea for creating supranational institution that will regulate the international trade.

For that purpose it was draw up the Havana Charter for establishing the International Trade Organization (ITO), a tool whose main goal was creating international collaboration in the field of employment, economic activity, economic development and reconstruction, trade policy, restrictive business practices and intergovernmental agreements. This Charter has never entered into force because it was not ratified by the US congress.

Despite the unsuccessful negotiations for creating the ITO, on October 301947 in Geneva 23 countries signed the General Agreement on Tariffs and Trade (GATT), which was the only international tool for regulating the International Trade until 1995 when the WTO was created.

The GATT`s main purpose was global and gradual reduction of tariffs and non-tariffs barriers and implementing other trade and political measures within the trade relations between signatory countries, in order to liberalize the world trade which was gradually realized by the numerous rounds of negotiations.

The GATT`s subscription was political and security attempt for countries' unification through mutual economic cooperation. The main specific of GATT is that, it is not an organization, but an Agreement composed of 38 articles which are bringing out the basic principles of trade liberalization. Therefore, the GATT does not consist of member countries, but it consists of "contracting countries" or "signatory countries".

Among them, significant number and place are taking the Developing countries, whose part in the negotiation rounds has increased from 10 developing countries participating in the GATT's establishment up to over $70 \%$ of the current 160 member countries.

\subsection{The fundamental GATT principles}

The GATT's activity is based on several fundamental principles contained in the text of the Agreement (See file: https://www.wto.org/english/docs_ellegal_e/gatt47_e.pdf):

1. The trade should be accomplished on non-discriminatory basis, applying the Most Favored Nation clause (MFN).

2. GATT prohibits the use of quantitative restrictions.

3. Tariff rates and non-tariff barriers reduction by accomplishing multilateral negotiations.

4. Common consultations of the signatory countries for removing trade barriers.

The GATT's principles are official and obligatory for all signatory countries, but the question is, whether they are based on or are adjusted to the needs, possibilities and interests of the different signatory countries, considering the fact that significant number of developing countries also took part in GATT`s establishment.

The practice shows numerous deviations from the GATT's principles while regulating the international trade, especially when it's a question of developing countries and their treatment in the international trade system.

\subsection{The GATT's role and goals in International Trade}

Due to the efforts for establishing rules, order and control over the international trade exchange and facilitating the same between all countries, GATT has being playing the role of permanent international forum within which are discussed and analyzed all aspects of the international trade and are signed numerous agreements for trade regulation. One of the GATT's fundamental assignments is allowing signatory countries to approve mutual tariff withdrawals and facilitations in order to promote the international trade and prohibiting the use of new or increasing the current barriers in front of the international trade.

The GATT realizes its activity through accomplishing multilateral trade negotiations. GATT has conducted eight negotiation rounds for reducing the tariff and non-tariff barriers in the international trade from which the last three (the Kennedy round, the Tokyo round and the Uruguay round) deserve special attention due to their contribution in the 
process of international trade liberalization. The $8^{\text {th }}$ round of negotiations within the GATT - The Uruguay round, began in September 1986 in Punta Del Este and ends on December 15, 1993 after seven years of hard negotiations between 125 contracting countries.

Finally in 1993 the most important negotiators the USA and the EU has adjusted their standpoints and on April 15, 1994 the Marrakesh Declaration has been signed by the 128 countries and the Uruguay round has officially ended and the World Trade Organization was established (WTO Legal Text, 2003, p.4).

The main elements of the Uruguay round Agreement are distributed in three main areas:

Reduction of agricultural subsidies;

Regulating the foreign investments related to international trade;

Starting the process of free trade with services such as banking and insurance.

The most significant negotiations result is the Agreement for reducing and in some cases complete removing of the tariff and non-tariff barriers in the international trade. This leads to increased reliability and confidence in the world, increased investments flows and world output growth.

The negotiations within the Uruguay round were critical for providing safe and secure future of the world economy and the trade system. The free trade has become the major pillar of the economic prosperity and worldwide development. The GATT creators managed to establish a set of procedures that ensure stability of the trade environment and facilitating the rapid growth of the world trade.

\subsection{The World Trade Organization (WTO)}

The World Trade Organization is the "youngest" one of the contemporary international institutions, which completes the institutionalization process of the international economic relations. The WTO is one of the fundamental and most significant results of the Uruguay round of multilateral negotiations held within the GATT.

The WTO is an international institution within which are regulated the trade relations between countries on a multilateral level in order to achieve faster and more progressive development. The aim of this organization is supporting the trade and economic relations between member countries oriented towards raising the living standard, full employment, increasing the purchasing power and the real incomes of the population, increasing and expanding the production and trade in goods and services at the optimum resources utility.

WTO has been lead by the three international general agreements such as: The General Agreement on Tariffs and Trade - GATT; The General Agreement on Trade in Services - GATS and The Agreement on Trade-Related Aspects of Intellectual Property Rights - TRIPS (See file: https://www.wto.org/english/docs_e/legal_e/legal_e.htm\#TRIPs).

Due to the WTO activity the international market access has been facilitated and the international trade barriers significantly reduced.

\subsection{WTO Fundamental Principles}

The WTO is based on the fundamental GATT's principles previously elaborated. Furthermore, the WTO stands for national economy protection by implementing tariffs; further tariff reduction through multilateral trade negotiations; converting the non-tariff instruments into tariffs; transparency; unification of the protection policies; principle of special treatment for developing countries and special dispute settlement mechanism (Simova, 2003, p.185).

In order to increase the transparency of the national foreign-trade policies, the WTO regularly publishes Reports for the trade reforms trend and for the problems that countries are facing with during the reforms. Therefore, the member countries have an obligation to submit information for their foreign-trade policies to the WTO Secretariat. Also, the WTO is providing technical help and assistance to the least developed countries for preparing their reports (Jovanovic and others, 1999, p 552).

\subsection{The WTO Agreements}

With the WTO membership, member countries are obligatory accepting and applying without exception the following Agreements (WTO: http://www.wto.org/english/theWTO_e/whatis_e/tif_elagrm1_e.htm):

Multilateral Agreements for Trade in Goods (GATT 1947, 1994)

Agriculture

Sanitary and phytosanitary measures 
Textile and clothes

Technical trade barriers

Measures related to the Intellectual Property Rights

Anti-dumping

Customs valuation

Rules of origin

Import licenses

Subsidies and compensatory measures

Safeguard measures

General Agreement on Trade in Services (GATS)

Agreement on Trade-Related Aspects of Intellectual Property Rights (TRIPS)

All Agreements within the WTO are highlighting the principles of liberalization and allowed exceptions. They include obligations for reducing the tariff rates and other trade barriers and liberalization of the services market.

Within the Agreements is also assigned procedure for dispute settlement and special treatment for the developing countries. In addition, the members governments should provide greater transparency of their trade policies, through constant reporting of the WTO regarding the laws that are in force and about measures adopted and submit reports to the Secretariat for countries ' trade policies. The main purpose of the Secretariat is monitoring, adjusting and harmonizing the economic policies of the countries.

\subsection{Results of the 20 years WTO activity}

1. This year the World Trade Organization (WTO) celebrates 20 years of successfully regulating the world trade flows, 20 years of successfully adjustment and harmonization of economic and trade policies of the member countries and 20 years of adjustment and satisfying the interests of all countries in the world regardless their level of development, aiming to achieve the Millennium Goals.

2. The World Trade Organization and the system of transparent, multilaterally-agreed rules that it embodies, has made a major contribution to the strength and stability of the global economy. Over the years the WTO has helped to boost trade growth, resolve numerous trade disputes and support developing countries to integrate into the trading system. It has also provided a bulwark against protectionism, the value of which was made plain in the trade policy response to the 2008 crisis, which was very calm and restrained in contrast to the protectionist panic that followed previous crises (https://www.wto.org/english/news_e/news15_e/dgra_01jan 15_e.htm). Indeed, when the global economy is more interconnected than ever, it is difficult to imagine a world without the WTO. Moreover, at the 9th Ministerial Conference in Bali in 2013, the negotiators took the first major step forward in updating multilateral trade rules. The measures agreed in Bali were a real breakthrough for the WTO, and they will provide a significant economic boost. In December 2014 WTO Members came together to recommit to implementing all aspects of the Bali package ${ }^{1}$.

3. What does it mean the Bali Declaration? In fact the Bali Declaration is a deal reached on several areas of negotiations such as: a package for Least Developed Countries (LDCs), Trade facilitation and Agriculture. These are very sensitive issues especially for the LDCs, because the WTO members confirmed their commitment to duty free, quota free market access for LDCs, but these countries could not completely use these concessions because of their limited export capacity. Regarding the Trade facilitation, the WTO members conclude that developing countries and the LDCs will need additional finance and technology in order to improve the process of Trade facilitation and they will support these countries in building capacities to be able to implement this agreement. The negotiations on Agriculture regarding the food -stock holding as usual were very vulnerable and sensitive which resulted with conclusion that more negotiations will still be required in order to be found a permanent solution. The deal in Bali gave a bit of hope that the long lasting Doha Round of negotiations will finally start to move even very slow towards the and long expected end of the round.

4. The WTO leaders this year will have a lot of work to do and many challenges to meet, because despite the

\footnotetext{
1 The Bali Package consists of draft decisions and declarations in two parts: Part I regarding the regular work under the General Council and Part II regarding work under the Doha Development Agenda.
} 
success of Bali, the pace of negotiations still is going to be a source of frustration. Beside the significant level of integration of all member countries into the trading system, the poorest members (LDCs) are still not adequately integrated into this system, so it is obvious that they still need additional help and assistance and additional aid for trade development and utilizing the benefits that the trade system can offer.

The latest World Trade Report 2014 shows the results of up to now WTO functioning in the service of global trade development and support of the developing and least developed countries in their integrating process in the world trading system. In this regard, the developing countries showed how they have successfully used the trade in order to facilitate their development and achieved economic growth, growing integration of global production through supply chains, higher prices for agricultural goods and natural resources.

According to the latest Trade report, incomes in developing countries are approaching to those of rich countries. Data in Figure 1 shows that, since 2000, GDP per capita of developing countries has grown by 4.7 per cent, with developing country G-20 members performing particularly strongly. Meanwhile developed countries only grew by 0.9 per cent. As a result, developing countries now account for more than half of world output in purchasing power parity terms (World Trade Report, 2014). The share of developing countries in global trade rose from 33 per cent to 48 per cent since 2000 , due to the significantly reduced MFN tariffs.

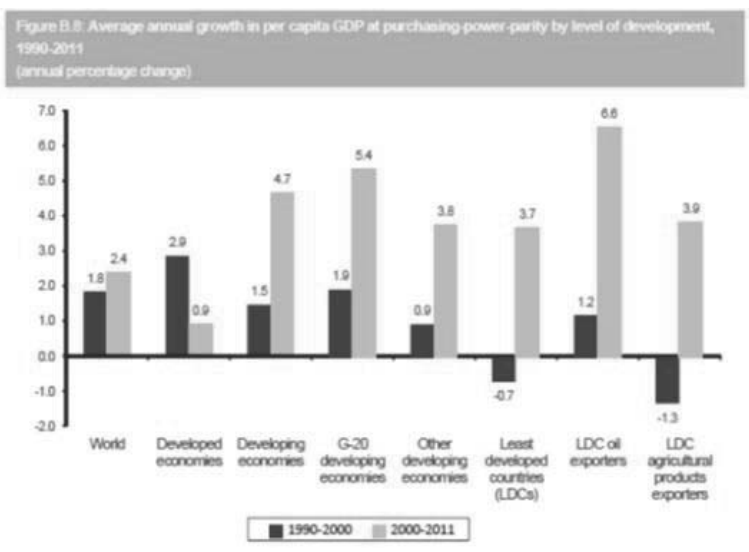

Figure 1. Average annual growth in per capita GDP at purchasing-power-poverty by level of development 1990-2011; Source: (World Trade Report 2014)

\subsection{WTO and Development}

The WTO has underpinned the progress made by many developing countries by allowing them to take advantage of, adapt to and mitigate risks arising from the trends achieved by these countries. Commitments under the WTO are important for developing countries to promote their trade and development. Countries undertaking substantial reforms in the context of WTO accession were found to grow 2.5 per cent faster for several years thereafter (https://www.wto.org/ english/news_e/pres14_e/pr728_e.htm). At the same time, developing countries need flexibilities because their economic circumstances can hamper their ability to implement obligations. Development is a fundamental objective of the WTO.

The latest trends in the World Trade Report 2014 show that trade is one of the key enablers of development. Trade has played a central role in lifting millions of people out of poverty in recent years and helped to achieve many of the UN millennium development goals (MDGs). The recent rise of Developing countries proved that, growth can lead to improvement of human development indicators; Trade is an important driver of growth; better environmental outcomes do not automatically follow and the environmental and social risks need to be anticipated and mitigated.

Also, another significant trend in the latest World Trade Report is the increasing participation of developing countries in the Global Value Chains (GVCs), where the WTO trade policies are crucial for GVCs development. The trend of higher commodities prices has opened export opportunities for many Developing countries and possibilities for further agricultural development, considering the fact that, Agriculture is key sector in developing countries employing more than half of population. 
It is a fact that, during the 20 years of WTO serving in service of World Economy, enormous development gains has been achieved, but still there is much more that needs to be done regarding the further development of DCs, upgrading their participation on GVCs, agricultural protection and subsidies and further strengthening of the rule-based system. Many of the needed is at hand in the Bali Decisions and the unfinished Doha Development Agenda.

The agreement reached in the Bali Ministerial Conference in December 2013 is a positive step in advancing this objective and offers many opportunities for developing countries. To make trade work more effectively for development, further progress on the Post-Bali Agenda would be important. The WTO and its central role and rules should be seen as an integral part of the enabling environment for realizing any post-2015 development agenda.

\section{Conclusion}

During all these years the WTO has justify its existence and action in the service of Institutionalization of the International Trade System, integration of all countries no matter their development level within the world trading system and providing opportunity for its benefits.

The WTO demonstrate that it is always in the function of international trade liberalization and facilitation of the market access as well continuous adjustment, harmonization and monitoring over the economic and trade policies of all member countries.

In this respect, ministers from every WTO member finally took a major step in updating multilateral rules by unanimously agreeing to the so-called Bali Package. The 10 decisions which make up the package have economic significance by themselves, particularly for developing countries, but together they also opened a new chapter for multilateral trade negotiations.

The WTO has still not achieved the acme of it's up to now functioning, because the top actually does not exist, it exists only one aim and that is levelling the differences in the world and providing equal chance to all countries in order to use the global benefits of the International Trade System.

In front of the WTO leaders stand much bigger challenges that are coming out from the measures established in the Bali package that in time should be implemented and should contribute for finishing the most lasting round of negotiations - Doha Round. This round should overcome all misunderstandings and contradictions between the WTO member countries, but with equal satisfaction of all countries` interests irrespective of their development level.

\section{References}

A. Simova, (2003), "The Globalization and the International Economic Organizations"

V. Marinov (2006)," International economic relations, theory, systems, politic"

Ministry of Economy of the R. Macedonia, (2006), "Doha Development Agenda, negotiations, implementation and development"

K. Efremov, (2009), "The Effects of Multilateral trade system liberalization towards the developing countries", (PhD diss., Economic Institute Skopje)

Ministry of Economy of the R. Macedonia, (2002), "Protocol for approaching the Republic of Macedonia towards the WTO"

WTO, (2003), "Results from the Uruguay round of multilateral trade negotiations", Legal texts

A. Hoda, A. Gulati, (2008) "The modalities on which developing countries can rely in WTO agriculture negotiations", IFPRI

Anthony P.Thirlwall, (2000) "Trade,Trade liberalization and Economic growth: Theory and evidence", Economic research paper No.63, (The African Development Bank)

F. Ismail, (2008) "Rediscovering the role of DC's in GATT before the Doha round", (RIS Discussion papers, RIS-Dp 141)

P.Jovanovic and others, (1999) "International Economic Relations", fourth edition, (Economic Faculty, Beograd)

Text of the General Agreement, Geneva, July 1986

\section{Website Resources}

https://www.wto.org/english/news_e/pres14_e/pr728_e.htm http://www.fao.org/docrep/003/x7352e/x7352e04.htm\#TopOfPage http://www.wto.org/english/theWTO_e/whatis_e/tif_e/fact4_e.htm 